\title{
Recycling and Standardization Aspects of Nigella sativa in the Food Industry
}

\author{
E.Yu. Egorova \\ Doctor of Technical Sciences, Professor of the Department \\ of technology of storage and grain processing, Institute \\ for Biotechnology, Food and Chemical Engineering, \\ Polzunov Altai State Technical University \\ Barnaul, Russia Federation \\ egorovaeyu@mail.ru
}

\author{
I.Yu. Reznichenko \\ Doctor of Technical Sciences, Professor, \\ Head of the Department of Quality Management \\ Kemerovo State University \\ Kemerovo, Russia Federation \\ irina.reznichenko@gmail.com
}

\author{
E.O. Ermolaeva \\ Doctor of Technical Sciences \\ of the Departmentof Quality Management \\ Kemerovo State University \\ Kemerovo, Russia Federation \\ eeo38191@mail.ru
}

\begin{abstract}
Black cumin seeds and products of its processing butter and semi-skimmed flour - have high nutritional and market value. At the same time, there are no unified state or international requirements and standard methodologies for confirming the authenticity and quality of butter, flour and food products that include them. The aim of this work is to analyze data on the composition of black cumin oil and flour and justify the list of regulated indicators and methods for confirming their authenticity and quality. The paper analyzes data on the chemical composition of black cumin oil. The limits of the content of the most physiologically important fatty acids - Linoleic, Linolenic and Eicosadienoic - are recommended for standardization and confirmation of the authenticity of fatty oil; standardization method is recommended. Data on the content of terpenes in the essential black cumin oil is summarized, the variability of the composition and content of the prevailing terpenes is shown. According to the results of studies of black cumin seed flour, a list of regulated organoleptic and physico-chemical indicators of the quality of this food raw material has been proposed.
\end{abstract}

Keywords - food technologies, oilseeds, Nutritive value, standardization, Nigella sativa.

\section{INTRODUCTION}

In recent years, Russian enterprises have been processing oilseeds that differ significantly in composition and technological properties: nuts, milk thistle, sesame, amaranth, black cumin, apricot stone, and others. The lack of state and international standardized requirements governing the identification and quality control of certain types of oilseeds and essential oil raw materials imported into the territory of the Russian Federation by processing enterprises necessitates the definition of a list of recommended indicators and methods for identifying the products of these raw materials and confirming their commercial quality and nutritional value.

So, for example, at present, amaranth seeds are purchased and processed by Russian enterprises in accordance with GOST 28636-90 "Seeds of little-spread forage crops. Sorting and sowing characteristics. Specification" and GOST R 552942012 "Seeds of minor fodder crops. Sowing characteristics. Specifications". From 01/01/2019, GOST 34221-2017 "Seeds of medicinal and aromatic crops. Varietal and sowing characteristics. General specifications" etc. will act on the seeds of milk thistle and enotery (oslinnik). This is despite the fact that according to GOST R ISO 5507-2012 "Oilseeds, vegetable oils and fats. Nomenclature" standardized terminology for these types of oils have already been defined - pumpkin oil, oslinnik oil, black cumin oil, etc. (as an example: for milk thistle and amaranth seed oils in regulatory documents for the food and processing industry not even standard names are set).

In the pharmaceutical industry,identification of plant raw materials requires a description of the external signs of whole and / or crushed raw materials, microscopic analysis of crosssection fragments, and comparison of microphotographs in order to compare key diagnostic features. Similar techniques are recommended for the identification of black cumin seeds (Nigella sativa). From January 2017, Russia introduced GOST ISO 5561-2015 "Black and blond caraway, whole. Specification" to black cumin. This regulatory document regulates a number of physicochemical parameters typical for essential oil raw materials: maximum permissible moisture content, total and insoluble ash, a lower threshold of essential oil content. Indicators and methods of analysis, that would allow to control the composition of essential or fatty oil and to confirm the type and degree of raw materials freshness at the stage of its acceptance or in the mode of production, are not specified in this document. At the same time, only the description of the appearance and, partially, morphological features does not reflect the full extent of theblack cumin seeds characteristics. Primarily, it does not give the idea of the technological value of this raw material for the oil and fat industry.

Gallic, p-dihydroxybenzoic, chlorogenic, p-coumaric, ferulic, lilac, vanillic, trans-2-hydroxycinnamic and trans- 
cinnamic acids, catechins and flavonoids $[1,2]$ were found in the composition of polyphenolic and phenolic compounds of black cumin seeds. About $1 \%$ of protein substances are found in seeds in the form of peptides, due to which black cumin seeds are considered promising for preparing drugs with antibiotic and antitumor activity [3]. The study of black cumin peptides focuses on thionin, which also exhibits a pronounced inhibitory effect on viruses, bacterial and yeast pathogens $[3,4]$, pathogenic fungi and oomycetes [5].

Five years ago, the only commercial product obtained from black cumin seeds in Russia was considered to be fatty oil for food purposes. Analysis of the food market shows that today black cumin oil is represented on the Russian market with more than 250 assortment positions. This applies to products of both Russian and foreign production. In addition to edible oil, Russian enterprises also supply for sale "flour" from black cumin seeds (Fig. 1a) - ground and sifted cake (Fig. 1b), obtained by pressing for oil.

At home - in Egypt, Morocco, the United Arab Emirates, Tunisia, Yemen, Syria, Turkey, India, Bangladesh, West Bengal, the countries of the Mediterranean, and West Asia as well as the world market in general, black cumin seeds are a widespread spice. However, black cumin seed oil at the same time retains the position of a niche product [6] with a limited target audience, as well as evening primrose (oslinnik), argan, ogurechnik (borage) oil and some others.

Due to the presence of thymoquinone in the composition of black cumin oil - an active ingredient with proven pharmacological properties - the seeds and oil of black cumin began to be considered not only by medical, but also by food industry, as innovative product with great potential $[7,8]$.This caused a sharp increase in the growth of the said niche in the
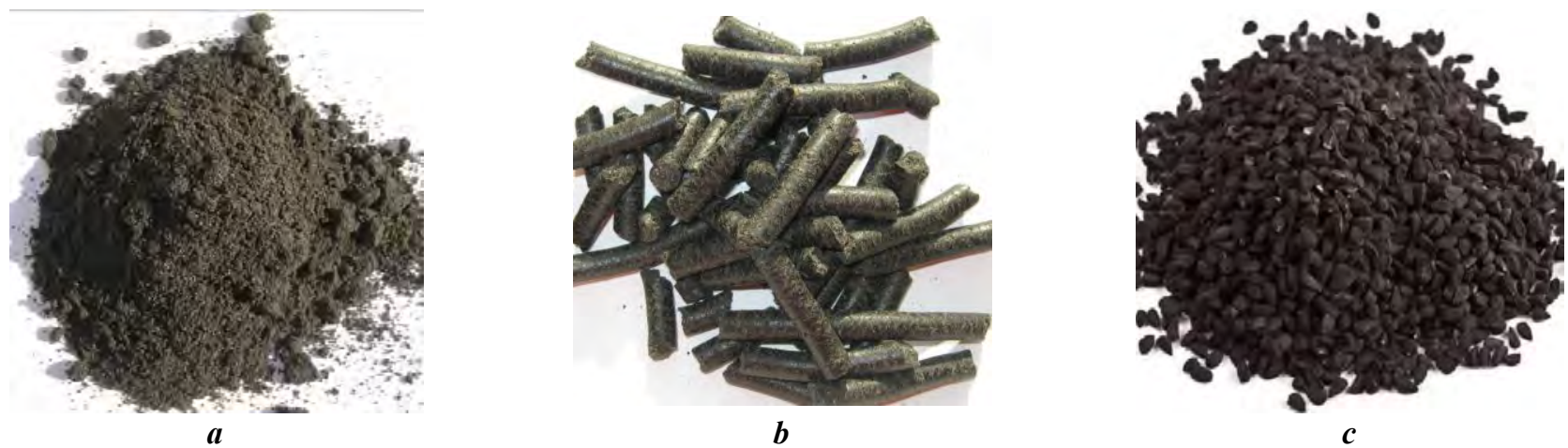

Fig. 1. Flour (a) and meals (b) of black cumin oilseed (c)

It is established that the oil contains characteristic triacylglycerols with 11Z, 13Z-eicosadienoic acid, that allow to establish the authenticity of the oil [11].

The growth of scientific interest in black cumin and the popularity of black cumin oil among the population noted in recent years should probably be attributed to the popularization of scientific data on the pronounced physiological properties of both the oil itself and the seeds as a whole. The number of publications annually confirms the pronounced therapeutic consumer market [6] and became one of the main reasons for the falsification of black cumin oil. This aspect determines the relevance of identifying the identification criteria and the development of controlling methods for the authenticity and quality of both the oil itself and the products fortified with it.

Methods for standardization of products obtained using black cumin seeds, both in Russia and abroad, are only being developed. To date, there is no express methods to confirm the authenticity of black cumin oil. Today, when black cumin is actively processed and sold as a valuable oilseed raw material, the question of confirming the authenticity of its processed productsas food products is becoming particularly acute.

Black cumin oil has a high biological value. In its composition 36 components are identified (polyunsaturated fatty acids, carotenoids, tocopherols, phytosterols), but the available data are still not systematized. There are no general approaches to standardization, both for butter and flour from black cumin seeds, and for food products fortified with it.

During the processing of black cumin seeds by pressing essential oil is releasedsimultaneously with fatty oil. One of the most active components of this essential oil is consideredt bethymoquinone, that exhibits cytotoxicity against tumor cells $[9,10]$. In this connection, an introduction of the quantitative content of thymoquinone in black cumin oil to the list of mandatory indicators can acquire certain prospects.

Russian experts have proposed using the "chromatographic profile" data obtained by reversed-phase HPLC with refractometric detection to confirm the authenticity of the black cumin oil. effect of seeds and black cumin oil on a number of diseases associated with the respiratory, gastrointestinal, immune, cardiovascular and nervous systems, including type 2 diabetes and cancer $[10,12-16]$.

It has been shown that the inclusion of black cumin seeds in the dietary nutrition significantly reduces the risk of complications in diabetes and oncology [17-20], accelerates the repair of liver and kidney cells during chronic intoxication of the body [7, 20,21], and accelerates the recovery of damaged 
tissues of the gastrointestinal tract. [8, 22]. The use of black cumin oil in suppressing allergic reactions is associated with the probable antihistamine properties of the oil and the inhibition of enzymes responsible for the metabolism of arachidonic acid $[23,24]$.

There are confirmed positive effects in terms of consumer properties of food with products of black cumin processing. In particular, the introduction of black cumin oil into flour confectionery products helps to reduce the rate of oxidative processes in the fatty phase of the product, allowing you to increase the expiration date [25]. The components of the essential oil exhibit a pronounced antibacterial effect $[4,26,27]$, due to which black cumin seeds and essential oil are proposed to use as natural preservatives in food production.

A feature in the characteristics of the oil and flour produced from black cumin seeds is the lack of a clear systematization of data on their chemical composition. It is important that within the limits of the species, different varieties of black cumin initially have certain differences, both in color and shape of the seeds, and in the content of the main components. In its turn, the equipment used by the operating enterprises may differ significantly in its performance, and this is enclosedwith the production of black cumin flour with different residual oil

\section{OBJECTS AND METHODS OF RESEARCH}

\section{B. Objects of research}

- currentregulatorydocumentson oil and meals of industrial crops;

- blackcuminseedoil;

- blackcuminflour, developed under the conditions of two operating specialized enterprises of the Altai Territory in 2017 and stored until research at a temperature of $4 \pm$ $2{ }^{\circ} \mathrm{C}$

\section{Methods of research}

A review of scientific publications was made on the basis of a comparative analysis and systematization of data from periodicals, current regulatory documentation and Internet resources.

Data on the content of black cumin flourmacrocomponents was obtained using standard research methods adopted in the oil and fat industry.

Mass fraction of moisture and volatile substances - drying the samples to constant mass at a temperature of $103 \pm 2^{\circ} \mathrm{C}$, with subsequent weighing and calculating the value of the indicator in $\%$.

Mass fraction of crude protein, in $\%$ of the solids content, according to the Kjeldahl method.

The residual fat content - extraction-weight method, in $\%$ of the solids content.

The content of crude fiber - by the method of GennebergShtoman, sequential processing of samples of black cumin flour with solutions of acid and alkali, followed by ashing and calculation of the indicator in $\%$ of dry nonfat flour substance. content. All this, as well as the lack of unified regulatory documents on the state or international level regulating the requirements for the quality of black cumin processing products as food raw materials, seriously complicates the justification of the directions of their use in the food industry.

In this regard, the aim of the work is to analyze data on the composition of oil and flour from black cumin seeds and justify the list of regulated indicators and methods for confirming their authenticity and quality.

Solved problems:

- analysisofthecurrent state of research on the chemical composition, biological and therapeutic properties of black cumin seeds;

- analysisofdataon the chemical composition of black cumin oil, justification of the criteria for the standardization of oil;

- determining the content of macro-components in the composition of black cumin flour, justification of regulated qualityandsafetyindicators.

The mass fraction of ash was determined by calcining samples weighing $5 \mathrm{~g}$ at a temperature of $700^{\circ} \mathrm{C}$ until complete ashing (set when the crucible reached a constant weight), followed by weighing and calculating the value of the indicator in $\%$ of the dry nonfat flour substance.

For each indicator, the studies were performed in 3-4 times. Data analysis was performed with the SPSS package (SPSS 6.0 for Windows, SPSS Inc., Chicago, IL, USA).

\section{RESULTS AND DISCUSSION}

Fundamental factors in the formation of food quality are raw materials and technology.

Modern Russian enterprises engaged in the processing of black cumin seeds, usually, use a single cold-pressed technology. However, there are no unified approaches, both to the instrumental and technological design of the method of extracting oil, and to assessing the quality of oil and black cumin flour.

For oil, usually, according to the documentation of manufacturing enterprises, color, taste and smell, the content of the amount of PUFAs and safety indicators are regulated. The list of regulated quality indicators for flour from black cumin seeds includes moisture, the content of ash insoluble in hydrochloric acid solution, metal-magnetic and impurities, fiber content, much lesscommon - protein and fat content.

According to authors from countries supplying black cumin to the European and Russian raw materials markets, the oil content in black cumin seeds ranges from 28 to $40 \%[6,26]$. The highest oil content is characterized by black cumin seeds, supplied from Iran, Saudi Arabia, Morocco and Yemen [6].

Published information on the composition of black cumin oil components cannot be considered complete. Despite a significant amount of scientific publications on the therapeutic 
properties of black cumin seeds and its individual components, data on the composition of fatty acids and terpenes are relatively few. Thus, a different oil content may well be accompanied by a different content of individual fatty acids and the accompanying lipids and fat-soluble vitamins. However, information on the composition and content of related components in the scientific literature is virtually absent.

Table I contains excerpts from scientific publications characterizing the lipid composition of black cumin seeds. Analysis of these data shows that the content of the three physiologically most important fatty acids - Linoleic, Linolenic and Eicosadienoic - can vary within fairly wide limits:

- Linoleic - from 33.2 to $63.71 \%$ of the amount of fatty acids;

- Linolenic - from 0.4 to $2.38 \%$;

- Eicosadienoic - from 2.05 to $6.24 \%$.

The standards adopted by Russian enterprises on the content of the amount of PUFAs confirmed at the stage of certification of black cumin oil do not reflect the content of linolenic and eicosadienoic acids. The value of the established standard (the content of the amount of PUFA) can be achieved due to the content of one linoleic acid, and this acid in significant quantities is part of the majority of industrially produced oils.

At present, the standard and standard method for analyzing the composition of fatty acids of vegetable oils is gas-liquid chromatography, with preliminary hydrolysis and methylation of samples. When statistically sufficient information is collected on the content of individual fatty acids in the composition of black cumin oil, this method can be recommended as reliable and sufficient to confirm the authenticity of black cumin oil, as well as for other types of valuable oils. This should stipulate the need for a clear regulation of the content limits of the three most important fatty acids: Linoleic, Linolenic and Eicosadienoic.

In addition to fatty oil, black cumin seeds contain essential oil - from 0.4 to $2.5 \%$ [26, 28, 29]. The main components in the composition of the essential oil is generally considered thymoquinone, $p$-cymene and $\alpha$-pinene (Table II). At the same time, an analysis of the published data on the composition of the black cumin essential oil indicates a critical for the standardization of the run-up of the possible values of the content of these terpenes. So, the content of p-cymene varies from 8.6 to $46-56.2 \%$, $\alpha$-pinene - from 1.11 to $13.75 \%$, thymoquinone - from $0.5-0.6$ to $50-76.7 \%$.

To a large extent, the content of individual terpenes depends not only on the geography of the raw material, but also on the method of extracting the essential oil. It is noted that the highest content of thymoquinone has oil from seeds grown in Turkey [36] When using supercritical fluid extraction, the content of thymoquinone in black cumin essential oil can reach $76.7 \%$, and in the case of distillation it can decrease to $0.5-4.3 \%$ [34] .

Almost all the tabulated data on the composition and content of black cumin terpenes was obtained for pure essential oil, isolated by distillation. The composition of terpenes, characteristic of such an essential oil, does not correspond to the qualitative composition (and quantitative content) of terpenes, which have been converted to fatty oil in the process of its production by pressing. In the extraction of fatty oil, a large part of the terpenes are extracted together with triacylglycerides, but their composition and content also significantly vary and very much depends on the properties of the extractant used [37].

TABLE I. COMPOSITION OF FATTY ACIDS OF SEEDS OIL OFNIGELLA SATIVA

\begin{tabular}{|c|c|c|c|c|c|c|c|}
\hline \multirow[t]{2}{*}{ Acids name and Index } & \multicolumn{7}{|c|}{ Composition of fatty acids, according to the source ${ }^{a}$} \\
\hline & [6], Morocco & [8] & [28], Iran & [30] & [31] & [32], Pakistan & [33], Tunis \\
\hline Lauricacid $(\mathrm{C} 12: 0)$ & - & - & 0.6 & - & - & - & - \\
\hline Myristic acid (C14:0) & $1.0 \pm 0.1$ & + & 0.5 & 0.20 & - & $0.12 \pm 0.004$ & 0.14 \\
\hline Pentadecyclic acid (C15:0) & - & - & - & - & 0.34 & - & - \\
\hline Palmitic acid (C16:0) & $13.1 \pm 0.2$ & + & 12.5 & 13.00 & 13.88 & $12.68 \pm 0.5$ & 8.92 \\
\hline Palmitoleic acid (C16:1) & $0.2 \pm 0.1$ & - & - & - & 0.26 & $0.12 \pm 0.005$ & 0.18 \\
\hline Margarinicacid (17:0) & - & - & - & - & 0.14 & - & - \\
\hline Geptadecenicacid (17:1) & - & - & - & - & 0.12 & - & - \\
\hline Stearic acid $(\mathrm{C} 18: 0)$ & $2.3 \pm 0.1$ & + & 3.4 & 2.85 & 5.31 & $3.99 \pm 0.15$ & 2.44 \\
\hline Oleic acid (C18:1) & $23.8 \pm 0.1$ & $20-24$ & 23.4 & 24.60 & 12.84 & $28.55 \pm 0.75$ & 19.42 \\
\hline Linoleic acid (C18:2) & $58.5 \pm 0.1$ & $50-60$ & 55.6 & 55.70 & 33.20 & $51.80 \pm 1.45$ & 63.71 \\
\hline Dihomolinoleicacid (C18:2) & - & 10 & - & - & - & - & - \\
\hline Linolenic acid (C18:3) & $0.4 \pm 0.1$ & $0.83-2.38$ & 0.4 & 0.64 & 0.44 & - & 0.44 \\
\hline Arachidicacid (C20:0) & $0.5 \pm 0.1$ & 3 & - & 0.22 & 0.28 & $0.21 \pm 0.003$ & 0.13 \\
\hline Eicosenoic acid (C20:1) & - & - & - & - & - & $0.48 \pm 0.01$ & 0.27 \\
\hline Eicosadienoic acid (C20:2) & 2.70 & - & 3.1 & - & 6.24 & $2.05 \pm 0.05$ & 0.33 \\
\hline Behenicacid (C22:0) & - & - & - & - & - & - & 2.89 \\
\hline Lignocericacid (C24:0) & - & - & - & - & - & - & 1.04 \\
\hline Total saturated acid & $16.8 \pm 0.5$ & 30 & - & 16.05 & - & 17.00 & 15.56 \\
\hline Total unsaturated acid & $82.9 \pm 0.5$ & 70 & - & 83.95 & - & 83.00 & 84.34 \\
\hline
\end{tabular}


TABLE II. COMPOSITION OF TERPENE ESSENTIAL OIL SEEDS OFNIGELLA SATIVA

\begin{tabular}{|c|c|c|c|c|c|}
\hline \multirow[t]{2}{*}{ Component name } & \multicolumn{5}{|c|}{ Composition of fatty acids, according to the source ${ }^{a}$} \\
\hline & [20] & [28], Iran & [29] & [34], Turkey & [35],Tunis \\
\hline$\alpha$-Thujene & - & 2.4 & 6.0 & $0.3-17.5$ & - \\
\hline Camphene & - & - & 11.0 & - & $<0.05$ \\
\hline Sabinene & - & 1.4 & 1.0 & до 2 & 1.66 \\
\hline$p$-Cymene & 40 & 14.8 & 22.05 & $8.6-56.2$ & 43.58 \\
\hline$\alpha$-Pinene & \multirow{2}{*}{15} & 1.2 & 1.11 & до 3.8 & 13.75 \\
\hline$\beta$-Pinene & & 1.3 & 7.0 & до 4.2 & 3.00 \\
\hline$\beta$-Myrcene & - & 0.4 & 0.21 & - & 0.94 \\
\hline$\alpha$-Phellandrene & - & 0.6 & 0.45 & $<0.05$ & - \\
\hline Limonene & + & 4.3 & 0.13 & до 2.9 & 2.55 \\
\hline$\alpha$-Terpinene & - & - & - & до 0.7 & $<0.05$ \\
\hline$\gamma$-Terpinene & - & 0.5 & 5.12 & до 1.2 & 1.4 \\
\hline Terpinolene & - & - & 0.23 & - & 9.08 \\
\hline Terpinen-4-ol & + & 0.7 & - & $0.6-1.4$ & 4.25 \\
\hline Borneol & - & - & 0.43 & - & - \\
\hline Bornyl acetate & - & - & - & до 0.8 & $<0.05$ \\
\hline Camphor & - & - & 1.0 & $<0.05$ & - \\
\hline Carvacrol & + & 1.6 & 10.0 & $0.6-2.5$ & 2.53 \\
\hline Carvone & + & 4.0 & 0.32 & $0,8-1,3$ & - \\
\hline Carvenol & - & - & - & - & 0.79 \\
\hline$p$-Cymenene & - & - & - & $<0.05$ & - \\
\hline$p$-Cymene-8-ol & - & 0.4 & - & до 0.2 & - \\
\hline Linalool & - & - & - & до 0.1 & - \\
\hline Linalool acetate & - & - & - & $<0.05$ & - \\
\hline Dihydrocarvone & - & 0.3 & - & - & - \\
\hline Fenchone & - & 1.1 & - & - & - \\
\hline Thymoquinone & до 50 & 0.6 & 20.32 & $0.5-76.7$ & 1.65 \\
\hline Dithymoquinone & + & - & - & - & - \\
\hline Thymohydroquinone & + & - & - & $<0.05$ & - \\
\hline Thymol & + & - & 10.12 & $<0.05$ & 1.67 \\
\hline$\alpha$-Longipinene & - & 0.3 & - & $0.6-0.9$ & 0.95 \\
\hline Longicyclene & - & - & 0.9 & - & - \\
\hline Longifolene & - & 0.7 & - & $1.8-2.6$ & - \\
\hline Estragole & - & 1.9 & - & - & - \\
\hline Citronellol & + & - & - & - & - \\
\hline$\beta$-Cyclocitral & - & - & - & до 0.4 & - \\
\hline Anisaldehyde & - & 1.7 & - & - & - \\
\hline trans-Anethole & - & 38.3 & - & - & - \\
\hline Myristicin & - & 1.4 & - & - & - \\
\hline$\beta$-Caryophyllene & - & - & - & до 0.4 & - \\
\hline$\alpha$-Bisabolene & - & - & - & - & $<0.05$ \\
\hline$\beta$-Bisabolene & - & - & - & до 0.3 & - \\
\hline$\gamma$-Cadinene & - & - & - & до 0.9 & - \\
\hline Dillapiole & - & 1.8 & - & - & - \\
\hline Junipene & - & - & - & - & 2.41 \\
\hline$\alpha$-amorphene & - & - & - & - & 0.62 \\
\hline Apiole & - & 1.0 & - & - & - \\
\hline (2E,6E)-Farnesol & - & - & - & $<0.05$ & - \\
\hline Estragole & - & - & - & - & 0.91 \\
\hline Germacrene & - & - & - & - & 1.06 \\
\hline
\end{tabular}

In turn, the variability of the content of essential oil in the seeds indicates the unreliability and unacceptability of the indicator "content of essential oil" for the purpose of standardization of black cumin.

Quantitative analysis of thymoquinone, dithymoquinone and thymol by HPLC or gas-chromatography-mass spectrometry to confirm the authenticity of the black cumin terpenes composition can only be recommended if statistically reliable data on the composition and content of terpenes in the oil obtained from black cumin seeds is compressed. And only in combination with the analysis of the quantitative content of the above-noted PUFA in fatty oil.

Identification of thymoquinone, dithymoquinone and thymol by TLC, proposed at the time byAbouBasha L.I. with co-authors [38] and Velho-Pereira R.M. with co-authors [39], allows to confirm the replacement of black cumin oil with less valuable oils, but makes it impossible to identify cases of simple dilution.

As noted above, both in Russia and in the international standardization system, there are no unified requirements for the quality and safety of food meal from oilseeds. With a single 
pressing, the release of edible oil from black cumin seeds includes only the free lipid fraction. As a result, meals and flour (as a final product of seed processing) from black cumin seeds are characterized by a rather high residual oil content (Table III).

The main limitation of the food use of oilseed and essential oil crops cakes isexcessive fiber content and the presence of specific anti-nutritional substances [40]. In the seeds of black cumin such components are not identified. Taking into account the obtained data on the macrocomponent composition, the most promising areas for the development of new food products (including fortified and functional) for black cumin flour can be considered obtaining flour and emulsion fatty products.

Oilseed meal is characterized by a disordered course of destructive, hydrolytic and oxidative processes inherent in the destroyed cells of any oilseeds. Black cumin flour is characterized by the presence of rapidly oxidized PUFA. In this regard, it is advisable to additionally introduce oxidative damage indicators into the list of regulated safety indicators of black cumin seed flour - acid and peroxide values, normalized with into account the residual oil content.

\section{CONCLUSION}

Numerous studies of the chemical composition and properties of black cumin seeds indicate that these raw materials are promising for the production of enriched food products and require clear criteria for standardization.

Analysis of the data on the chemical composition of black cumin oil found that the most important fatty acids are Linoleic, Linolenic and Eicosadienoic. Control of the content of these fatty acids in the composition of black cumin oil by gas-liquid chromatography can be recommended as a reliable and sufficient method to confirm the authenticity of black cumin oil. In this case, statistically sufficient information should be collected on the content of individual fatty acids in the composition of the oil, and the documents regulating the procedure for confirming the authenticity of black cumin oil should clearly specify the limits of Linoleic, Linolenic and Eicosadienoic acids.

TABLE III. ORGANOLEPTIC AND PHYSICAL-AND-CHEMICAL INDICATORS OF QUALITY OF BLACK CUMIN FLOUR

\begin{tabular}{|l|c|}
\hline \multicolumn{1}{|c|}{ Indicator name } & Indicator value \\
\hline Appearance and consistency & Homogeneous on the whole loose powder of dispersion less than 0.3 mm \\
\hline Colour & $\begin{array}{c}\text { Spicy-neutral } \\
\text { no moldy, musty, rancid and other foreign smells }\end{array}$ \\
\hline Smell & $\begin{array}{c}\text { d, spicy-hot. } \\
\text { Without moldy, musty, rancid and other foreign tastes }\end{array}$ \\
\hline Taste & $5.4-6.4$ \\
\hline M.f. of moisture and other volatiles, \% & $18.7-19.7$ \\
\hline $\begin{array}{l}\text { M.f. ofrawfatwhen converted into dry matter, } \% \\
\%\end{array}$ & $31.9-32.9$ \\
\hline $\begin{array}{l}\text { The content of crude fiber in terms of dry skimmed } \\
\text { substance, } \%\end{array}$ & $3.4-4.4$ \\
\hline M.f. of totalashin terms of dry skimmed substance, $\%$ & $6.7-6.9$ \\
\hline M.f. ofinsoluableash in terms of dry skimmed substance, $\%$ & $0.57-0.84$ \\
\hline
\end{tabular}

The content of essential oil in the black cumin seeds and the composition of its terpenes significantly depend on the geography of the black cumin collection and technology of their processing. In this regard, the indicator "essential oil content" cannot be considered reliable and acceptable for the standardization of black cumin and the products of its processing.

The study of the black cumin flour macro-components composition and the analysis of scientific data on the chemical composition of the seeds themselves show that the control of residual fat content must be included in the list of mandatory indicators of the quality of black cumin seed flour, since it is the oil that contains the main biologically active components considered raw materials.

\section{References}

[1] S.Bourgou, R.Ksouri, A.Bellila, I.Skandrani, H. Falleh, and A.B. Marzouk,"Phenolic composition and biological activities of Tunisian Nigella sativa L. shoots and roots",Comptes Rendus Biologies,Vol.331, No. 1, 2008, pp. 48-55, doi: 10.1016/j.crvi.2007.11.001.

[2] S.Cheikh-Rouhou, S.Besbes, G.Lognay, Ch.Blecker, C. Deroanne, and H. Attia,"Sterol composition of black cumin (Nigella sativaL.) and Aleppo pine (Pinus halepensis Mill.) seed oils",Journal of Food Composition and Analysis,Vol. 21, No. 2, 2008, pp. 162-168, doi.org/10.1016/j.jfca.2007.09.001.

[3] V.B. Kul'ko, O.V. Kisil, V.S. Sadykova, V.F. Mikhailov, I.M. Vasilieva, L.V. Shulenina, G.D. Zasukhina, and E.A.Rogozhin, "Investigation of thionins from black cumin (Nigella sativaL.) seeds showing cytotoxic, regulatory and antifungal activity", Antibiotics and Chemotherapy, Vol. 61, No. 9-10, 2016, pp. 8-16.

[4] A.S.Vasilchenko, A.N.Smirnov, S.K.Zavriev, E.V.Grishin, E.A. Rogozhin, and A.V. Vasilchenko,"Novel thionins from black seed (Nigella sativa L.) demonstrate antimicrobial activity",International Journal of Peptide Research and Therapeutics,Vol. 23, Iss. 2, 2017, pp. 171-180, doi: 10.1007/s10989-016-9549-1.

[5] Yu.I.Oshchepkova, O.N.Veshkurova, Sh.I.Salikhov, E.A.Rogozhin, A.Kh.Musolyamov, Ts.A.Egorov, E.V.Grishin, A.N. Smirnov, and T.I. Odintsova,"Isolation of the lipid-transporting protein Ns-LTP1 from seeds of the garden fennel flower (Nigella sativa)",Russian Journal of Bioorganic Chemistry,Vol. 35, No. 3, 2009, pp.344-349.

[6] S. Gharby, H. Harhar, D. Guillaume, A. Roudani, S. Boulbaroud, M Ibrahimi, M. Ahmad, Sh. Sultana, T.B. Hadda, I. ChafchaouniMoussaoui, and Z. Charrouf, "Chemical investigation of Nigella sativa L. seed oil produced in Morocco". Journal of the Saudi Society ofAgricultural Sciences, Vol.14, Iss.2, 2015, pp. 172-177, doi.org/10.1016/j.jssas.2013.12.001.

[7] S. Darakhshan, A.B. Pour, A.H. Colagar, and S. Sisakhtnezhad, "Thymoquinone and its therapeutic potentials", Pharmacological 
Research, Vol. 95-96, doi.org/10.1016/j.phrs.2015.03.011.

2015,

8] S.A. Khan, A.M. Khan, M.A. Kamal, G.A. Damanhouri, Z. Mirza, and S. Karim, "Panacea seed "Nigella": A review focusing on regenerative effects for gastric ailments", Saudi Journal of Biological Sciences, Vol. 23, No.4, 2016, pp. 542-553, doi.org/10.1016/j.sjbs.2014.10.001

[9] G.G. Martinovich, I.V. Martinovich, A.V. Vcherashniaya, O.I. Shadyro, and S.N. Cherenkevich,"Mitochondrial reactive oxygen species production and programmed tumor cell death induced by thymoquinone, a biologically active constituent of Nigella sativa", Biophysics, Vol. 61, Iss. 6, 2016, pp. 1164-1172.

[10] Z.Gholamnezhad, M.H. Boskabady, and S. Havakhah,"Preclinical and clinical effects of Nigella sativa and its constituent, thymoquinone: A review", Journal of Ethnopharmacology, Vol. 190, 2016, pp. 372-386, doi.org/10.1016/j.jep.2016.06.061

[11] V.I. Deineka, L.A. Deineka, A.V. Turtygin, and I.P. Anisimovich, "Inverse phase HPLC triacylglycerol black cumin and argan oils", Fat and oil processing industry, No. 1, 2010, pp. 26-27.

[12] M.S. Butt, and M.T. Sultan, "Nigella sativa: reduces the risk of various maladies", Critical Reviews in Food Science and Nutrition, Vol. 50, No. 7, 2010, pp. 654-665, doi: 10.1080/10408390902768797.

[13] E. Entok, M.C.Ustuner, C.Ozbayer, B.Yangi, H.Kurt, I.Degirmenci, H.V.Gunes, N. Tekin, and F. Akyuz,"Anti-inflammatuar and antioxidative effects of Nigella sativa L.: 18FDG-PET imaging of inflammation", Molecular Biology Reports,Vol. 41, No. 5, 2014, pp. 2827-2834, doi: 10.1007/s11033-014-3137-2.

[14] I.Bouasla, A.Bouasla, A.Boumendjel, M.Messarah, C.Abdennour, M.S. Boulakoud, and A. El Feki,"Nigella sativa oil reduces aluminium chloride-induced oxidative injury in liver and erythrocytes of rats",Biological Trace Element Research,Vol. 162, No. 1-3, 2014, pp.252261

[15] Z.Gholamnezhad, R. Keyhanmanesh, and M.H. Boskabady,"Antiinflammatory, antioxidant, and immunomodulatory aspects of Nigella sativa for its preventive and bronchodilatory effects on obstructive respiratory diseases: A review of basic and clinical evidence",Journal of Functional Foods, Vol. 17, August, 2015, pp. 910-927, doi.org/10.1016/j.jff.2015.06.032.

[16] A. Ahmad, A. Husain, M. Mujeeb, S.A. Khan, A.K. Najmi, N.A. Siddique, Z.A. Damanhouri, and F. Anwar, "A review on therapeutic potential of Nigella sativa: A miracle herb", Asian Pacific Journal ofTropical Biomedicine, Vol. 3, No. 5, 2013, pp. 337-352, doi.org/10.1016/S2221-1691(13)60075-1.

[17] J.Heshmati, N.Namazi, M.-R.Memarzadeh， M. Taghizadeh,and F. Kolahdooz,"Nigella sativaoil affects glucose metabolism and lipid concentrations in patients with type 2 diabetes: A randomized, doubleblind, placebo-controlled trial",Food Research International,Vol. 70, 2015, pp. 87-93, doi.org/10.1016/j.foodres.2015.01.030.

[18] M.T.Sultan, M.S.Butt, R.Karim, S.Z.Iqbal, S.Ahmad, M.Zia-Ul-Haq L.Aliberti, A.N. Ahmad, and V.De Feo,"Effect of Nigella sativa fixed and essential oils on antioxidant status, hepatic enzymes, and immunity in streptozotocin induced diabetes mellitus",BMC Complementary and Alternative Medicine,Vol. 14, 2014,p. 193,doi.org/10.1186/1472-688214-193.

[19] A.M. Mohamed, F.Z. EL-Sharkawy, S.A.A. Ahmed, W.M. Aziz, and O.A. Badary, "Glycemic control and therapeutic effect of Nigella sativa and Curcuma longa on rats with streptozotocin-induced diabetic hepatopathy", Journal of Pharmacology and Toxicology, Vol. 4, No. 2, 2009, pp. 45-57, doi: 10.3923/jpt.2009.45.57.

[20] M.E. Abd El-Hack, M. Alagawany, M.R. Farag, R. Tiwari, K. Karthik, and K. Dhama, "Nutritional, healthical and therapeutic efficacy of black cumin (Nigella sativa) in animals, poultry and humans", International Journal of Pharmacology, Vol. 12, No. 3, 2016, pp. 232-248, doi: 10.3923/ijp.2016.232.248

[21] A.H.El-Far, M.A.Korshom, A.A.Mandour, A.A. El-Bessoumy, and Y.S El-Sayed,"Hepatoprotective efficacy of Nigella sativa seeds dietary supplementation against lead acetate-induced oxidative damage in rabbit Purification and characterization of glutathione peroxidase",Biomedicine \& Pharmacotherapy,Vol. 89, 2017, pp. 711718, doi.org/10.1016/j.biopha.2017.02.044.
[22] M.-A. Magdy, El-A. Hanan, and El-M. Nabila, "Thymoquinone: nove gastroprotective mechanisms" European Journal of Pharmacology, Vol. 697, Iss.1-3, 2012, pp.126-131 doi.org/10.1016/j.ejphar.2012.09.042.

[23] S.Nikakhlagh, F.Rahim, F.H.Aryani, A.Syahpoush, M.G. Brougerdnya, and N. Saki,"Herbal treatment of allergic rhinitis: the use of Nigella sativa",American Journal of Otolaryngology,Vol. 32, No. 5, 2011,pp 402-407, doi:10.1016/j.amjoto.2010.07.019.

[24] K.Ipci, T.Oktemer, N.B.Muluk, E.Şahin, N.Altintoprak, S.A.Bafaqeeh, Y.Kurt, R.Mladina, M. Šubarić, and C. Cingi,"Alternative products to treat allergic rhinitis and alternative routes for allergy immunotherapy", American Journal of Rhinology \& Allergy,Vol. 30, No. 5, 2016, pp. 8-10, doi: 10.2500/ajra.2016.30.4364

[25] V.A. Artemyeva, T.A. Yamashev, and O.A. Reshetnik, "The effect of black cumin oil on the resistance to oxidation of the fatty phase of a flour confection during storage", Problems of Nutrition, Vol. 85, No. S2, 2016, p. 131 (InRussian).

[26] M.Arici, O. Sagdic, and U. Gecgel,"Antibacterial effect of Turkish black cumin (Nigella sativa L.) oils",Grasas y aceites,Vol. 56, No. 4, 2005, pp. 259-262, doi.org/10.3989/gya.2005.v56.i4.90.

[27] F. Forouzanfar, B.S. Fazly Bazzaz, and H. Hosseinzadeh, "Black cumin (Nigella sativa) and its constituent (thymoquinone): a review on antimicrobial effects", Iranian Journal of Basic Medical Sciences, Vol. 17, No. 12, 2014, pp. 929-938.

[28] B. Nickavar, F. Mojab, K. Javidnia, and M.A.R. Amoli, "Chemica composition of the fixed and volatile oils of Nigella sativa $L$. from Iran",Zeitschrift für Naturforschung, No. 58 (9-10), 2003, pp. 629-631.

[29] M. Kazemi, "Chemical composition and antioxidant properties of the essential oil of Nigella sativa L.", Bangladesh Journal of Botany, No1, 2015, pp. 111-116, doi: http://dx.doi.org/10.3329/bjb.v44i1.22732.

[30] A.S.AbdEl-Azeem, M.M.Hussein, F.M.Refai, El-S.M. Hegazy, and S.O Hussein,"Effects of Nigella sativa seeds and its oils fraction on some biochemical parameters in alloxan diabetic rats", Research Journal of Pharmaceutical, Biological and Chemical Sciences, No. 6 (3), May-June 2015, pp. 433-439.

[31] S.Y. Mashirova, and T.V. Orlovskaya, "Examination of lipid component of the Nigella sativa and Nigella damascena seeds", Belgorod State University Scientific Bulletin Medicine Pharmacy, No. 4 (123), Iss. 17, pp. 223-227 (In Russian).

[32] A.K. Aftab, S.A. Mahesar, A.R. Khaskheli, S.T.H. Sherazi, Q. Sofia, and K. Zakia, "Gas chromatographic coupled mass spectroscopic study of fatty acids composition of Nigella sativa L. (KALONJI) oil commercially available in Pakistan", InternationalFoodResearchJournal, No. 21 (4), 2014, pp. 1533-1537.

[33] C.-C. Toma, G.M. Simu, D. Hanganu, N. Olah, F.M.G. Vata C. Hammami, and M. Hammami, "Chemical composition of the Tunisian Nigella sativa. Note I. Profile on fatty essential oil", Farmacia, Vol. 61,Iss. 3, 2013, pp. 454-458.

[34] L. Kokoska, J. Havlik, I. Valterová, H. Sovova, M. Sajfrtova, and I. Jankovská, "Comparison of Chemical Composition and Antibacterial Activity of Nigella sativa Seed Essential Oils Obtained by Different Extraction Methods", Journal of Food Protection, Vol. 71, No. 12, 2008, pp. 2475-2480, doi: 10.4315/0362-028X-71.12.2475.

[35] C.-C. Toma, G.M. Simu, D. Hanganu, N. Olah, F.M.G. Vata, C. Hammami, and M. Hammami, "Chemical composition of the Tunisian Nigella sativa. Note I. Profile on essential oil", Farmacia, Vol. 58, Iss. 4, 2010, pp. 458-454.

[36] N. Ahmad, R. Ahmad, A. Al-layly, H. Al-shawi, A. Al-ali1, M. Amir, and A. Mostafa, "Ultra-high-performance liquid chromatography-based identification and quantification of thymoquinone in Nigella sativa extract from different geographical regions", Pharmacognosy Magazine, Vol. 14, Iss. 57, Jan. 2018, pp. 471-480, doi: 10.4103/pm.pm_119_18.

[37] K.H. Ghahramanloo, B. Kamalidehghan, H.A. Javar, R. Teguh Widodo K. Majidzadeh, and M.I. Noordin, "Comparative analysis of essential oil composition of Iranian and Indian Nigella sativaL. extracted using supercritical fluid extraction and solvent extraction", Drug Design, Development and Therapy, Vol. 11, 28 July 2017,pp. 2221-2226, doi https://doi.org/10.2147/DDDT.S87251.

[38] L.I. Abou Basha, M.S. Rashed, and H.Y. Aboul-Enein, "TLC Assay of Thymoquinone in Black Seed Oil (Nigella Sativa Linn) and Identification 
of Dithymoquinone and Thymol", Journal of Liquid Chromatography \& Related Technologies, Vol. 18, Iss. 1, Jan. 1995, pp. 105-115, https://doi.org/10.1080/10826079508009224.

[39] R.M. Velho-Pereira, C.R. Barhate, S.R. Kulkarni, and A.G. Jagtap, "Validated high-performance thin-layer chromatographic method for the quantification of thymoquinone in Nigella Sativa extracts and formulations", Vol. 22, Iss. 4, Feb. 2011, pp. 367-373, https://doi.org/10.1002/pca.1289.

[40] M.S.Bochkarev, E.Yu.Egorova, I.Yu.Reznichenko, and V.M.Poznyakovskiy, "Reasons for the ways of using oilcakes in food industry",Foods and Raw Materials, Vol. 4, No. 1, 2016, pp. 4-12, doi: 10.21179/2308-4057-2016-1-4-12. 